\title{
チュウゴクザサの開花における花序を切除した程と自然条件下の 稈の枯死過程の相違
}

阿部佑平 ${ }^{* 1,2)} \cdot$ 柴田昌三 ${ }^{1)}$

1）京都大学大学院農学研究科

2）現）香川県西部林業事務所 Forestry Office
Graduate School of Agriculture, Kyoto University

Kagawa Prefectural Government West Region

摘要 : 本研究ではチュウゴクザサを対象に, 花序を切除した稈と自然条件下の稈の一斉開花とその翌年の開花に おける枯死過程の相違を明らかにすることを目的に, 花序や地下茥の切断処理を行い, 花・種子生産量と稈の枯 死過程を調査した。調査の結果，無処理の稈に関して，一斉開花における 1 回目の開花では, 結実率, 枯死稈 の割合は小さかったが，2 回目の開花において結実率は大きくなり，枯死秙の累積割合は $95 \%$ となった。花序 を切除した稈に関しては, 1 回目の開花で枯死㷏は確認されず，2 回目の開花において枯死稈の累積割合は $25 \%$ であった。同様の傾向は地下茎を切断した㷏と地下茎及び花序を切断した稈の間でも確認され, 2 回目の開花に おいて, 地下茎を切断した程は 1 回目の開花より結実率が大きくなり枯死秙の累積割合は $93 \%$ となったが, 地 下茎及び花序を切断した秙の枯死秙の割合は $53 \%$ であった。一斉開花で枯死しなかった稈は, 翌年も開花して 枯死した。これらのことから，チュウゴクザサの一斉開花において，花序を切除した場合は枯死する稈の割合が 小さくなること，一斉開花で枯死しなかった稈は翌年も開花して最終的には全て枯死することが示唆された。 キーワード : チュウゴクザサ, 開花, 花生産量, 種子生産量, 稈の枯死

ABE, Yuhei and SHIBATA, Shozo: Differences in the culm dying-out process between inflorescence-cut culms and control culms in flowering of the dwarf bamboo Sasa veitchii var. hirsuta

Abstract: In this study, the authors investigated flower and seed production and the status of inflorescence/rhizome-cut culms for the dwarf bamboo Sasa veitchii var. hirsuta in order to clarify differences in the culm dyingout process between inflorescence-cut culms and control culms in mass flowering and subsequent flowering. The results revealed that the seed set ratio and the dead-to-total-culm ratio (known as the dead culm ratio) were small in the first flowering, and that the seed set ratio was larger and the dead culm ratio was $95 \%$ for control culms in the second flowering of the mass-flowering event. Culm death was not observed in the first flowering, and the dead culm ratio was $25 \%$ for inflorescence-cut culms in the second flowering of the mass-flowering event. The similar tendency was observed for rhizome-cut culms and rhizome- and inflorescence-cut culms. The seed set ratio was larger than that observed in the first flowering and the dead culm ratio was $93 \%$ for rhizomecut culms in the second flowering of the mass-flowering event. For rhizome- and inflorescence-cut culms, the dead culm ratio was $53 \%$ in the second flowering of the mass-flowering event. Culms that did not die in the mass-flowering event flowered and died the following year. These results suggest that inflorescence cutting makes the dead culm ratio smaller than that observed in natural conditions in mass flowering. It was also observed that inflorescence-cut culms finally die the year after mass flowering, and that a high seed set ratio causes marked culm death in natural conditions.

Key word: Sasa veitchii var. hirsuta, flowering, seed production, flower production, culm de

\section{1.はじめに}

日本の暖温帯域と冷温帯域において森林の下層を優占する ササ属の種（以下「ササ」と表記する）は，60～100 年に一 度開花して枯死するといった特異な開花習性を有する ${ }^{9)}$ 。サ サは庭園に植栽されるなど, 緑化植物として重要である ${ }^{6.7,8)}$ 。 そのため, ササの開花に関する生態学的な知見は, 緑地の保 全や緑化植物としての利用を図るうえで重要である。

ササの開花に関しては, 一斉に開花した場合, 多数の種子
が生産され，開花終了後に枯死するとの報告が多い10,12,13,14)。 一方，ササがまとまって開花したが種子はほとんど生産され なかった事例もあり, その場合, 開花しても必ずしも枯死し なかったことが確認されている ${ }^{5,11}$ 。夕ケ・ササ類は, 開花 において種子生産に多くの資源を消費するため枯死すると指 摘されている4)。これらのことから, ササが開花しても種子 生産量が大きくない場合, 枯死を引き起こすほど資源が消費 されない可能性があると考えられる。最近の研究では, 花の 生産にも資源を消費し, 種子生産量が少なくても枯死につな 
がる場合があることが報告されている ${ }^{11}$ 。種子生産量が大き い場合に稈が枯死するのであれば，ササを緑化植物として利 用している場面においては, 稈の枯死を防いで緑を維持する ために, 花序を切除して種子生産を阻害する等の対処を行え ると考えられる。一方, 種子が生産されなくても花を生産す ることでも枯死するのであれば, 都市近郊の緑地にササが分 布する地域に押いて, 虫害の影響2)等で結実率が小さかった 場合, 開花枯死後のササの更新が困難になる可能性があるこ とは，緑地保全上の考慮すべき点であると考えられる。花・ 種子の生産と稈の枯死の関係は, ササの開花に関する生態的 特性の中でも重要な事項であり, その関係を明らかにするに は自然条件下の稈と花序の切除等により種子生産を阻害した 稈の枯死過程を比較することが有益である。また，地下茎の 切断等によって生存を維持する資源が限られた秙を設定し, 種子生産を阻害する場合と阻害しない場合の枯死過程を比較 すれば，前述の関係をより明確にできると考えられる。しか し, 研究事例が少なく花・種子の生産と秙の枯死の関係は明 確になっていない。

京都市においては, 北部山間地域にチュウゴクザサ（Sasa veitchii (Carrière) Rehder var. hirsuta (Koidzumi) S. Suzuki) が分布し, 近年, 一斉に開花した ${ }^{1}$ 。そこで本研究ではチュ ウゴクザサを対象に, 花・種子の生産と稈の枯死の関係に関 する知見を得るため, 自然条件下の稈と花序を切除した稈の 開花における枯死過程の相違を明らかにすることを目的に, 両稈の花・種子の生産量, 稈の枯死過程を調査した。

\section{2. 調查方法}

\section{1 調查地の概要}

調査は, 京都市北部山間地域の北東部に位置する大見地区 (緯度 $\mathrm{N} 35.11^{\circ}$, 経度 $\mathrm{E} 135.48^{\circ}$, 標高 $622 \mathrm{~m}$ ) で行った (図一 1)。調査地から南南西に約 $15 \mathrm{~km}$ 離れたところにある京都 大学上賀茂試験地（緯度 $\mathrm{N} 35.09^{\circ}$, 経度 $\mathrm{E} 135.47^{\circ}$, 標高 109 225 m) に打ける年平均気温は $14.6^{\circ} \mathrm{C}$, 年平均降水量 は $1,582 \mathrm{~mm}$ であり, 本調查地は上賀茂試験地と比べ標高差 が 400 500 m あることから, 気温聥減率を $0.6^{\circ} \mathrm{C} / 100 \mathrm{~m}$ と すると, 調查地付近の年平均気温は上賀茂試験地より $2 \sim 3$ ${ }^{\circ} \mathrm{C}$ 低い $11.6^{\circ} \mathrm{C} \sim 12.6^{\circ} \mathrm{C}$ と推察される。大見地区では, ミズ ナラ (Quercus crispula Blume) やクリ (Castanea crenata Siebold et Zucc.), リョウブ (Clethra barbinervis Siebold et Zucc.), ネジキ (Lyonia ovalifolia (Wall.) Drude var. elliptica (Siebold et Zucc. Hand.-Mazz.)) 等から構成される二次林の 下層にチュウゴクザサが生育している。大見地区を含む京都 市北東部地域では, 2007 年に東西 $12 \mathrm{~km}$, 南北 $16 \mathrm{~km}$ の範 囲にわたってチュウゴクザサが一斉に開花した1)。

\section{2 調査対象種}

チュウゴクザサの開花は, 開花が 4 月から 7 月にかけて 2 度生じた ( 1 回目の開花 : 4 月〜 5 月, 2 回目の開花 : 6 月〜 7 月) ${ }^{1}$ 。 ササは風媒花であり ${ }^{15)}$, 花序は 4 ～10 個の小花を有す る小すいから構成される円錐形花序で, 果害は堅果である ${ }^{17)}$ 。

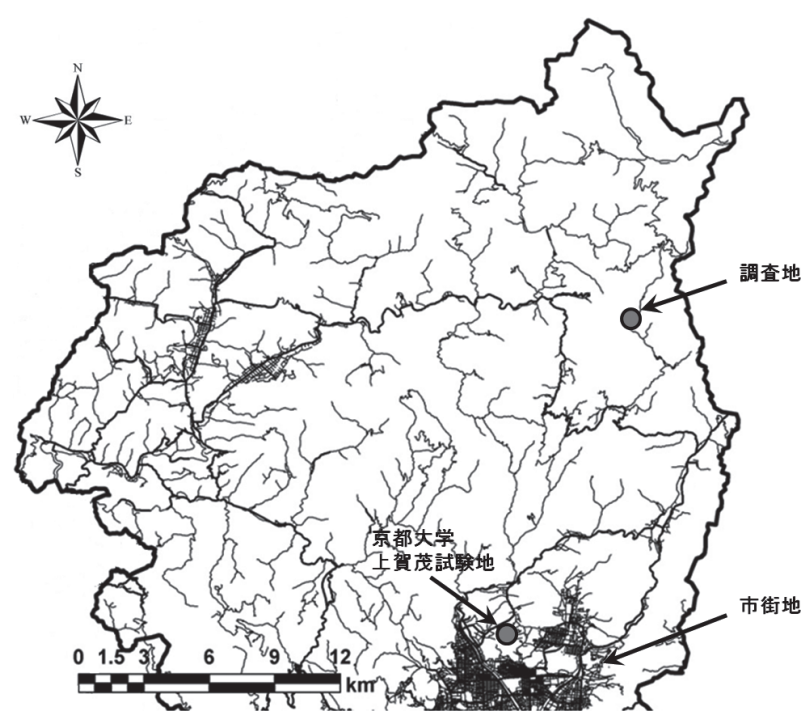

図-1 調査地の位置

太線は京都市の境界, 細線は京都市内の主要な道路を示す。

Fig 1 Location of study site

Bold and fine lines indicate border of Kyoto City and main roads, respectively

\section{3 調查方法}

チュウゴクザサの開花における自然条件下の稈と花序を切 除した稈の枯死過程の相違を明らかにするため, 斜面下部の 広葉樹林約 0.2 ha の範囲内のチュウゴクザサ個体群を対象 に, 調查を行った。2007 年 3 月下旬に, チュウゴクザサ個 体群内から調查対象の程どうしの間隔が $5 \mathrm{~m}$ 程度はあくよ うに無作為に 70 稈を選択し, 各稈を $\mathrm{A} \sim \mathrm{D}$ のいずれかのグ ループに分け，異なる処理を行った（図-2）。調查対象稈の グループ分けに関しては, 調查地内に 4 グループが交ざり 合うように，無作為に行った。

グループ A：無処理（自然条件下） $(\mathrm{n}=20)$

グループ B : 一斉開花の 1 回目と 2 回目それぞれの開花に

おいて, 花序が伸長し小花が開く前に花序を切除 $(\mathrm{n}=20)$ グループ C : 花序が伸長し始める前の 2007 年 4 月上旬に,

稈が発生している部分の地下茎を $10 \mathrm{~cm}$ 程度残して地

下茥を切断 $(\mathrm{n}=15)$

グループ D : 花序が伸長し始める前の 2007 年 4 月上旬に,

㷏が発生している部分の地下茎を $10 \mathrm{~cm}$ 程度残して地 下茎を切断し, 一斉開花の 1 回目と 2 回目それぞれの 開花において, 花序が伸長し小花が開く前に花序を切除 $(\mathrm{n}=15)$

上記の処理に関して, 種子生産を阻害するためグループ B 及び D では小花が開く前に花序の切除を行ったものである。 また，ササは地下茎を伸ばして栄養成長を行う植物であり， 地下茎を通じて養分の転流を行うことも報告されている ${ }^{16)}$ 資源量が限られた稈の開花における枯死過程を調べれば, 花・種子の生産と稈の枯死の関係がより明確になると考え, グループ C 及び D では, 地下茥の切除を行ったものであ る。2007 年の一斉開花の 1 回目と 2 回目の開花に扔ける結 


\section{Group A (Control culms)}

Inflorescence

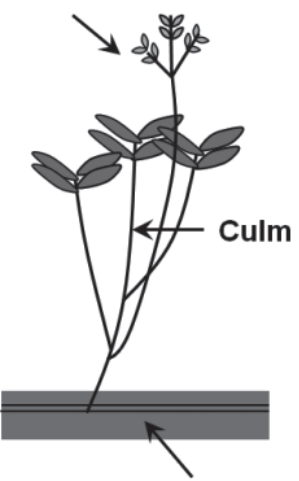

Rhizome
Group B

(Inflorescence-cut culms)

Cut of inflorescences

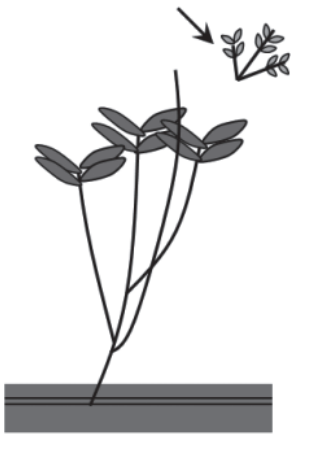

Group C

(Rhizome-cut culms)

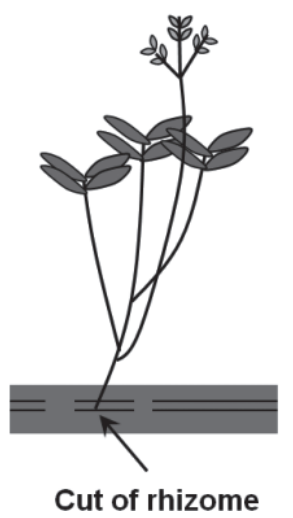

Group D

(Inflorescence- and

rhizome-cut culms)

Cut of inflorescences

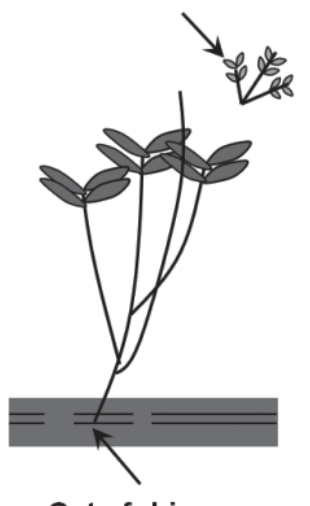

図-2 実験方法の模式図

グループ A：無処理（自然条件下），グループ B：一斉開花において小花が開く前に花序を切除，グループ C : 一斉開 花の直前に地下茥を $10 \mathrm{~cm}$ 程度残して切断, グループ D : 一齐開花の直前に地下茎を $10 \mathrm{~cm}$ 程度残して切断し, 小花 が開く前に花序を切除

Fig. 2 Schematic illustration of experimental methods

Group A: control; B: inflorescences cut before floret opening in the first and second flowering of the mass-flowering event; C: rhizome cut before mass flowering (length of remaining rhizome: approx. $10 \mathrm{~cm}$ ); D: rhizome cut before mass flowering and inflorescences cut before floret opening in the first and second flowering of the mass-flowering event (length of remaining rhizome: approx. $10 \mathrm{~cm}$ )

実の段階において，それぞれのグループの各稈の状態（「生 存」「葉枯れ生存」,「枯死」) を確認した。花序を切除して いないグループ A，Cに関しては， 1 回目の開花及び 2 回目 の開花において，稈あたりの花序数，小花数，種子数を測定 し, 結実率（種子数 /小花数）を算出した。1 回目の開花に おける調査日は 6 月 17 日， 2 回目の開花における調査日は 7 月 28 日である。グループ B，D に関しては，各開花にお いて稈あたりの花序の数を測定した。2007 年の一斉開花で 枯死しなかった稈（「生存」及び「葉枯れ生存」の稈）に関し ては，翌年の 2008 年の 4 月下旬から 7 月上旬かけて，花序 の有無を確認し，2008年の7月下旬に各稈の状態を確認した。

なお，本研究における結実の段階とは，無処理の稈に関し て，種子が結実し落果する前の段階を指す。秙の状態に関し ては，葉及び稈ともに緑色をしている状態を「生存」，葉は 枯れて茶色になったが稈は緑色をしている状態を「葉枯れ生 存」, 葉及び秙ともに枯れて茶色になった状態を「枯死」と した。また，花序の切除や地下茎の切断処理の直後に葉及び 稈が枯れることは確認されなかったため, 作業中に稈を傷め るようなことなく，切除・切断処理自体は適切にできたもの とみなした。

\section{3. 結 果}

調査の結果を表-1 に示す。 2007 年の一斉開花の 1 回目の 開花において, 各グループ間で稈あたりの花序発生数に有意 な差は確認されなかった。無処理のグループ A に関しては, 結実率は $4.2 \pm 6.1 \%$ であり枯死状態となった稈は全体の
10.0\% であったが， $50.0 \%$ の稈は葉枯れ生存状態となった。 花序を切除したグループ B に関しては, 枯死した稈は確認 されなかったが, 全体の $25.0 \%$ の程が葉枯れ生存状態と なった。地下茎を切断したグループCに関しては, 稈あた りの小花生産量は無処理のグループ A りり有意に小さく, 結実率は $3.3 \pm 5.9 \%$ であり全体の $33.3 \%$ の稈が枯死し， $40.0 \%$ の稈が葉枯れ生存状態となった。地下茥を切断して 花序を切除したグループ D に関しては, 全体の $20.0 \%$ の程 が枯死し， $60.0 \%$ の稈は葉枯れ生存状態となった。

2007 年の一斉開花の 2 回目の開花において, 1 回目の開 花で枯死しなかった稈は再び開花した。2 回目の開花におい ても, 各グループ間で稈あたりの花序発生数に有意な差は確 認されなかった。無処理のグループ A に関しては, 結実率 は $30.7 \pm 16.7 \%$ であり全体の $95.0 \%$ の稈が枯死状態となっ たが，花序を切除したグループ B に関しては，枯死状態及 び葉枯れ生存状態の稈がそれぞれ全体の $25.0 \%$ であった。 地下茥を切断したグループ C に関しては, 稈あたりの小花 生産量及び結実率は無処理のグループ A より有意に小さく, 全体の $93.3 \%$ の稈が枯死状態となり, 地下茎を切断して花 序を切除したグループ D に関しては, 全体の $53.3 \%$ の程は 枯死状態， $40.0 \%$ の稈は葉枯れ生存状態となった。

2007 年の一斉開花において枯死しなかった稈は，翌年の 2008 年に再び開花し，その開花の終了時には，どのグルー プも全ての稈が枯死状態となった。 
表-1 花序・地下茎の切除処理を行った稈の花・種子の生産量と開花枯死の動態

Table 1 Flower/seed production and the process of flowering and culm death throughout mass flowering and subsequent flowering for each group

\begin{tabular}{|c|c|c|c|c|}
\hline \multirow[b]{2}{*}{ Variable } & \multicolumn{4}{|c|}{ Group } \\
\hline & $\begin{array}{c}\mathrm{A} \\
(\mathrm{n}=20)\end{array}$ & $\begin{array}{c}\text { B } \\
(n=20)\end{array}$ & $\begin{array}{c}\mathrm{C} \\
(\mathrm{n}=15)\end{array}$ & $\begin{array}{c}D \\
(n=15)\end{array}$ \\
\hline \multicolumn{5}{|l|}{2007 (mass-flowering year) } \\
\hline \multicolumn{5}{|l|}{ First flowering } \\
\hline Number of inflorescence per culm & $2.4 \pm 1.0$ & $2.2 \pm 1.0$ & $2.0 \pm 0.9$ & $2.3 \pm 1.1$ \\
\hline Nmber of floret per culm & $239.3 \pm 114.1 \mathrm{a}$ & - & $150.9 \pm 74.9 \mathrm{~b}$ & - \\
\hline Seed set ratio per culm (\%) & $4.2 \pm 6.1 \mathrm{a}$ & - & $3.3 \pm 5.9 \mathrm{a}$ & - \\
\hline \multicolumn{5}{|l|}{ Cumulative number of culms } \\
\hline Living & $8(40.0)$ & $15(75.0)$ & $4(26.7)$ & $3(20.0)$ \\
\hline Living with withered leaves & $10(50.0)$ & $5(25.0)$ & $6(40.0)$ & $9(60.0)$ \\
\hline Dead & $2(10.0)$ & $0(0.0)$ & $5(33.3)$ & $3(20.0)$ \\
\hline \multicolumn{5}{|l|}{ Second flowering } \\
\hline Number of inflorescence per culm & $1.4 \pm 0.8$ & $1.2 \pm 0.6$ & $1.1 \pm 0.9$ & $1.2 \pm 0.7$ \\
\hline Nmber of floret per culm & $177.6 \pm 101.3 \mathrm{a}$ & - & $68.1 \pm 45.6 \mathrm{~b}$ & - \\
\hline Seed set ratio per culm (\%) & $30.7 \pm 16.7 \mathrm{a}$ & - & $11.3 \pm 11.7 \mathrm{~b}$ & - \\
\hline \multicolumn{5}{|l|}{ Cumulative number of culms } \\
\hline Living & $1(5.0)$ & $10(50.0)$ & $1(6.7)$ & $1(6.7)$ \\
\hline Living with withered leaves & $0(0.0)$ & $5(25.0)$ & $0(0.0)$ & $6(40.0)$ \\
\hline Dead & $19(95.0)$ & $5(25.0)$ & $14(93.3)$ & $8(53.3)$ \\
\hline \multicolumn{5}{|l|}{2008 (year after mass flowering) } \\
\hline \multicolumn{5}{|l|}{ After second flowering } \\
\hline \multicolumn{5}{|l|}{ Cumulative number of culms } \\
\hline Living & $0(0.0)$ & $0(0.0)$ & $0(0.0)$ & $0(0.0)$ \\
\hline Living with withered leaves & $0(0.0)$ & $0(0.0)$ & $0(0.0)$ & $0(0.0)$ \\
\hline Dead & $20(100.0)$ & $20(100.0)$ & $15(100.0)$ & $15(100.0)$ \\
\hline
\end{tabular}

数值は平均值と標準偏差。グループ間で異なるアルファベットは有意差があることを示す（小花数及び結実率：Mann-Whitney U test, $P<0.05)$ 。括弧内の数值は，各グループに関して，全体の㷏数に対する生存稈数または枯死稈数の割合。

Values are means \pm standard deviations. Letters after numbers represent the level of statistical significance among treatments (Mann-Whitney $\mathrm{U}$ test for floret production and seed set ratio per culm: $p<0.05$ ). Values in parentheses are cumulative percentage ratios of living or dead culms to total culms for each group.

\section{4. 考 察}

夕ケ・ササ類は種子生産量が顕著であった場合に枯死する ことが指摘されており ${ }^{3)}$, 稈が枯死する原因は, 種子生産に 多くの資源を消費し，稈を再生するための資源が残らないか らである ${ }^{4)}$ と報告がなされている。京都市大見地区での チュウゴクザサの一斉開花における 1 回目の開花では, 無 処理の稈に関して, 結実率, 枯死した稈の割合は小さく, 花 序を切除した程に関しては, 枯死した稈は確認されなかった (表-1)。一方, 2 回目の開花において, 無処理の稈では結 実率が上昇し，それに伴い $95 \%$ の稈が枯死したが，花序を 切除した㷏に関しては, 枯死したものは $25 \%$ であった。同 様の傾向は地下茥を切除した程と地下茥及び花序を切除した 稈の間においても確認され, 地下茥を切除した秙は, 2 回目 の開花において結実率が上昇し，93\%の稈が枯死したが, 地下茥及び花序を切除した程に関しては，枯死したものは $53 \%$ であった。本研究結果は, 上記の既存の考えを裏付け
るものであり，チュウゴクザサの一斉開花において，花序を 切除して種子生産を阻害した場合には枯死稈の割合が小さく なることが示唆された。

ササに関する先行研究では, 結実率が $0 \sim 0.1 \%$ で種子が ほとんど生産されなくても, 規模の大きい開花の場合, 開花 後は稈の地上部が枯死することが確認されており, 花の生産 にも多くの資源を消費することが指摘されている ${ }^{11)}$ 。本研究 においては, 全グループに関して, 一斉開花の 1 回目の開 花で枯死した稈は少なかったが, 4 分の 1 から半数の稈は葉 枯れ生存状態となり, 花序を切除した程に関しては, 2 回目 の開花終了時に半数から 9 割の稈が葉枯れ生存または枯死 状態となった。さらに, 地下茥を切断された稈は, 生存を維 持する資源量が制限されていると考えられ, 無処理の程と比 較して, 花序発生量は同程度であったが, 1 回目の開花にお いて小花生産量は小さく, 結実率は同程度であるものの枯死 状態の秙の割合は大きかった。2 回目の開花において, 同㷏 は, 無処理の稈より結実率は小さいが，ほとんどの稈が枯死 
した。これらの本研究結果は, 種子生産量がわずかでも開花 後に稈の枯死が確認された前述の先行研究 ${ }^{11}$ の報告と矛盾し ない。さらに, 本研究では, 2007 年の 2 回の一斉開花にお いて枯死しなかった稈は，翌年再び開花して全て枯死した。 大見地区におけるチュウゴクザサの一斉開花の翌年の開花で は，ほとんど種子が生産されなかったことが確認されてい る ${ }^{2}$ 。これらのことから花序を切除して種子生産を阻害した 場合でも，花の生産により資源を消費すること，一斉開花で 枯死しなかった稈は翌年も開花し，最終的には枯死すること が示唆された。

上記のような開花に関する生態学的特性をふまえると, チュウゴクザサの緑化植物としての利用にあたっては，花序 を切除して種子生産を阻害することで枯死を少しでも遅らせ ることはできるが，最終的には枯死することを考慮しておく ことが重要と考えられる。

\section{引用文献}

1) Abe, Y. and Shibata, S. (2012) Spatial and temporal flowering patterns of the monocarpic dwarf bamboo Sasa veitchii var. hirsuta. Ecol. Res., 27: 625-632.

2）阿部佑平・柴田昌三（2015）ヒメササノミモグリバエの幼 虫による散布前捕食がチュウゴクザサの一斉開花における 種子生産に与える影響, Bamboo J., 15: 1-9.

3) Campbell, J.J.N. (1985) Bamboo flowering patterns: A global view with special reference to East Asia. J. Am. Bamboo Soc., 6: 17-35.

4) Janzen, D.H. (1976) Why bamboos wait so long to flower. Ann. Rev. Ecol. Syst., 7: 347-391.

5) Kitamura, K. and Kawahara, T. (2007) Flowering culm dy- namics in sporadic flowering of Sasa cernua Makino. Bulletin of FFPRI, 6: 239-244.

6) 京都府立大学竹類文化研究会編（1994）京の竹地図. 東山 山麓コース, 京都府立大学竹類文化研究会

7) 京都府立大学竹類文化研究会編 (1995) 京の竹地図. 嵐山・ 嵯峨野コース, 京都府立大学竹類文化研究会

8）京都府立大学竹類文化研究会編（1996）京の竹地図. 京都 三大祭コース, 京都府立大学竹類文化研究会

9) Makita, A. (1998) The significance of the mode of clonal growth in the life history of bamboos. Plant Species Biol., 13: 85-92.

10) Makita, A., Konno, Y., Fujita, N., Takada, K. and Hamabata, E. (1993) Recovery of a Sasa tsuboiana population after mass flowering and death. Ecol. Res., 8: 215-224.

11) Miyazaki, Y., Ohnishi, N., Takafumi, H. and Hiura, T. (2009) Genets of dwarf bamboo do not die after one flowering event: evidence from the genetic structure and flowering pattern. J. Plant Res., 122: 523-528.

12）室井綽（1966） 夕ケ類の開花原因と鼠害, 富士竹類植物園 報告, 11: 7-38.

13）室井綽（1968）水の山におけるネマガリダケの開花, 富士 竹類植物園報告, 13: 90-106.

14）西脇亜也・葑田明史（1998）伊豆諸島御蔵島で 1997 年に 見られたミクラザサ (Sasa kurilensis var. jotanii) の一斉 開花における大量結実と発芽, Bamboo J., 15: 1-9.

15) Nishiwaki, A. and Konno, Y. (1990) Pollination system in two Japanese dwarf bamboo species. Bamboo J., 8: 17-20.

16) Saitoh, T., Seiwa, K. and Nishiwaki, A. (2002) Importance of physiological integration of dwarf bamboo to persistence in forest understorey: a field experiment. J. Ecol., 90: 78-85.

17）鈴木貞雄 (1978) 日本夕ケ科植物総目録, 学習研究社, 384pp. (2016 年 12 月 2 日 受理) 